\title{
From gynaecology offices to screening campaigns: a brief history of cervical cancer prevention in Brazil
}

Luiz Antonio Teixeira

Researcher, Casa de Oswaldo Cruz/Fiocruz; Professor, Masters Degree in Family Health/Universidade Estácio de Sá. Av. Brasil, 4036, sala 403

21040-361 - Rio de Janeiro - RJ - Brazil luiztei3@gmail.com

Received for publication in May 2013. Approved for publication in July 2014.

Translated by David Rodgers.

TEIXEIRA, Luiz Antonio. From gynaecology offices to screening campaigns: a brief history of cervical cancer prevention in Brazil. História, Ciências, Saúde - Manguinhos, Rio de Janeiro, v.22, n.1, jan.-mar. 2015.

Available at: http://www.scielo.br/hcsm.

\section{Abstract}

This paper discusses the knowledge and medical practices relating to cervical cancer in Brazil. It analyses the growing medical interest in the disease at the beginning of the twentieth century, the development of prevention techniques in the 1940s, and the emergence of screening programs in the 1960s. It argues that the development of knowledge on cervical cancer was related simultaneously to a number of factors: transformations in medical knowledge, the development of the idea that the disease should be treated as a public health problem, the increased concerns with women's health, and major changes to the Brazilian healthcare system. The article concludes by identifying a number of issues that are still proving to be obstacles to control of the disease.

Keywords: Neoplasms; cervical cancer; Pap smear; screening programs; Brazil. 
$\mathrm{M}$ edical interest in cervical cancer grew in the final decades of the nineteenth century with the emergence of theses and articles on the topic in medical journals. For a long time, though, medicine would remain without an effective weapon to either prevent or treat the disease, relying mainly on radical forms of surgery, involving amputation of the uterus, that very often proved lethal, and palliative care. Women, for their part, easily fell prey to the disease due to their reluctance to make their medical complaints public, whether because of social pressures or modesty, and only turning to doctors for help when their discomfort, pain and suffering became unbearable, by the time when the disease had advanced too far to be controlled.

Until the 1940s, in spite of the development of gynaecology and, in particular, the use of radiotherapy to treat cancer, the lack of a method for preventing cervical cancer meant that the search for early diagnosis through frequent gynaecological exams was limited to the few women with access to private medical practices. Following this period, the development of exfoliative cytology (the Papanicolaou test or Pap smear) and colposcopy as techniques for early detection and later prevention altered this scenario, allowing the actions taken to combat the disease to reach a larger number of women. However, reflecting the pattern in which Brazil's public health system historically developed, prevention techniques disseminated slowly and unequally in the country, transformed into large-scale actions only from the 1970s with the implantation of screening campaigns and later the emergence of a national program for controlling the disease.

Cervical cancer is directly associated with infection by human papillomavirus (HPV) - in most cases transmitted via unprotected sexual contact - and indirectly related to other factors such as a high number of sexual partners, tobacco smoking and lack of hygiene. These factors increase the risk of the disease among more disadvantaged sectors of the population, leading to its association with poverty and lower levels of education. The disease is a serious public health issue in Latin America, one of the regions with the highest occurrence rates in the world (Guerra et al., 2005).

Despite the long process of developing control actions, cervical cancer is still a major public health problem in Brazil, primarily affecting poorer women with less access to health services (Thuler, 2008). As the second most common type of cancer among Brazil's female population after breast cancer, the disease corresponds to the fourth highest cause of death of women from cancer in the country. ${ }^{1}$ The fact that cervical cancer remains high in the country's epidemiological indices reveals the limitations of Brazil's health system and prompts a wider discussion on the multiple factors involved in producing this situation.

Over recent decades, academic researchers working internationally on the history of the sciences, sociology and collective health have produced a diverse set of analyses concerning cervical cancer. Works in this field have focused on topics like the problems involved in standardizing the analysis of cytology slides and the difficulties of recruiting and training cytology technicians (Casper, Clarke, 1998); the organization of screening campaigns; the controversies surrounding the cost and effectiveness of these programs (Hakama et al., 1985); the role of laboratories in the process of stabilizing this technique (Singleton, 1998); the ideas of local communities concerning the Papanicolaou test (Gregg, 2003); and the overall trajectory of the bodies of knowledge and practices related to the disease (Löwy, 2011). These 
studies diverge considerably in their evaluation of specific elements of the history of cervical cancer screening, providing a range of different contributions to the topic.

Recent works have analysed the history of the disease in Brazil, focusing on the different models involved in developing techniques for its control along with its local specificities. The study on the control of cervical cancer in Argentina and Brazil produced by the Argentinean researcher Yolanda Eraso (2010) is a pioneering example of this approach, demonstrating how the two countries followed a different trajectory to most of the western medical world by using colposcopy ${ }^{2}$ as a basis for detecting cervical abnormalities until the 1960s. Her work shows that the interest in this technique developed out of the relations of cooperation between German, Brazilian and Argentinean gynaecologists in the years prior to the Second World War. After the end of the conflict, ties of cooperation were re-established between the German gynaecologists and their Latin American colleagues and a de facto network was instituted which disseminated colposcopy as a technique for detecting cervical cancer in these countries.

I recently explored the topic along similar lines in a work co-authored with the researcher Ilana Löwy. Our study looked to profile the use of colposcopy and cytology by Brazilian medical science, discussing how the longevity of this disease prevention model was related to particularities of the public health model and medical knowledge existing in the country. During the period when cervical cancer was treated only by private medicine and philanthropic initiatives of limited range, the broad use of colposcopy was an adequate solution for its prevention. However, when the disease became classified as a public health problem and taken as symptomatic of the failings of the health system, initiatives based on exfoliative cytology, which had a much broader demographic reach, became the baseline for its control (Teixeira, Löwy, 2011).

Based on a paper later presented at the seminar International Health/Global Health: historical perspectives from Latin America and the Caribbean (28-29 Jun. 2012), the article (Teixeira, Löwy, 2011) surveys the overall trajectory of cervical cancer in Brazil, as well as discussing specific aspects of the actions taken to control the disease in the country. Our premise was that the different forms of technico-scientific development and their outcomes in the field of the medical actions and health policies within each period and local context are shaped by the range of possible alternatives, related to the different socioeconomic configurations, the forms in which powers circulate between actors, and the distinct modes of scientific and professional organization (Latour, 2012). We believe that the analysis of this multiplicity of variables in its temporal continuum - a dimension made visible by the adoption of a historical perspective - can enrich the set of studies on the theme and shed some light on present-day actions to control the disease.

\section{The first steps taken in preventing cervical cancer in Brazil}

For a long time cervical cancer was a disease little known among Brazilian doctors. Between the mid nineteenth century and the beginning of the twentieth, the few works on the topic, published in medical journals, discussed the possibilities for diagnosis of the disease, surgical techniques suited to ablation of the uterus, and therapies making use of 
abrasive substances to cauterize the tumour (Gurgel, 1903). In the subsequent two decades, following the development of radiotherapy and radical hysterectomy techniques, doctors began to give more attention to the problem, divided between those advocating the use of one of these techniques as a treatment, or a combination of both, or even the use of radioactive substances like mesothorium. ${ }^{3}$

Regardless of the therapy used, the percentage of cure was tiny, limited to cases involving very small tumours. All the other cases, where other organs and tissues had been invaded, were incurable as a rule. During the period in question, medical care was provided to the population by a small number of philanthropic institutions - such as the Holy Houses of Mercy - and mutual fund societies, or by private and clinical physicians who provided care to wealthier sectors of the population. Public health services were confined to actions against epidemics and the regulation of urban life: chronic-degenerative diseases were not on their agenda. In this context, the large majority of Brazil's female population during the period had little or no access to doctors, succumbing to the disease without knowing what was killing them, or the best form of treating it (Teixeira, 2010).

During the first decades of the twentieth century, the medical discussions on cervical cancer intensified as part of a general growing concern over cancer. ${ }^{4}$ At the time, doctors postulated that, given the lack of any effective therapy, the best form of controlling the disease was early diagnosis, which they believed would allow the discovery of early-stage cases susceptible to treatment by radiotherapy or surgery (Teixeira, Porto, Noronha, 2012). The scant knowledge available on the disease's evolution initially led specialists to think that seeking out medical assistance as soon as the first symptoms appeared - abnormal bleeding, pains etc. - would be enough to deter its development. There was still no realization that even women who quickly went to a doctor when the first symptoms appeared could already be suffering from advanced-stage cancer and thus beyond any possibility of therapeutic treatment (Löwy, 2011).

A paper presented to the Brazilian Gynaecology Society in 1938 reveals the persistence of this form of thinking. Its author, Nabuco de Gouveia, asserted that his experience in American and European scientific centres showed how it was impossible to successfully treat the disease once established. In order to get round this problem, doctors should make women aware of their own key role in controlling the disease since only they could perceive the first symptoms of the initial cancer and seek medical advice. To achieve this aim, it was essential to instruct them properly in identifying the first signs of the disease, stressing the importance of early treatment. Nabuco pointed to the systematic efforts being made in European countries and the USA to this purpose. ${ }^{5}$

Some time before Nabuco's paper, at the beginning of the 1920s, research in the field of gynaecology conducted in European and American centres had begun to indicate ways of controlling cervical cancer. In 1924, the German gynaecologist Hans Hinselmann developed a type of binocular magnifying glass and adapted it to observing the cervix. The apparatus, named the colposcope, assisted in the diagnosis of cellular anomalies in the cervix and other gynaecological pathologies. In 1933, an Austrian gynaecologist, Walter Schiller, discovered that applying diluted iodine (Lugol) to the cervix made alterations easier to observe since the altered regions did not absorb the solution. The combination of these two methods colposcopy and Lugol staining - when used by a highly experienced technician enabled 
precursor lesions and small malignant lesions to be identified, which could then be cauterized (Löwy, 2011). These methods were used in Germany, Austria and Switzerland in the 1930s, but did not spread beyond these countries, with the important exception of Latin America where they arrived through the German scientific influence by the end of the decade. ${ }^{6}$

During the same period, pursuing his own distinct line of research, George Papanicolaou, a Greek physician working in the USA, discovered that by examining smears taken from the cervix he was able to detect the presence of lesions that could transform into cancerous growths. In 1941, in collaboration with the pathologist Herbert Traut, he published his first work on the technique of cytological diagnosis, which became known by his name (Papanicolaou, Traut, 1941). The observation of pre-cancerous abnormalities through the Papanicolaou test (or Pap smear) would then be followed by more specific examinations - such as colposcopy and directed biopsy - capable of confirming the seriousness of the problem. Despite the initial technical difficulties, the work of Papanicolaou and Traut quickly spread through the medical community as a core tool in preventing the disease, offering a low-cost and non-invasive method for detecting pre-cancerous abnormalities in women (Casper, Clarke, 1998). In much of the western world, the triad of cytology, colposcopy and biopsy - in that order - represented the model for preventing cervical cancer from the 1940s onwards. In the following decade, the diffusion of this technique would lead to the emergence of the first population screening campaigns for the disease, later transformed into national programs in various European countries (Löwy, 2011).

The first Brazilian studies in the field of cytology and colposcopy, directed towards preventing cervical cancer, started to be developed in university research institutions at the end of the 1930s within a wider context of a revival in gynaecology. In 1936, a chair in the discipline was created at the Rio de Janeiro Faculty of Medicine, making it a distinct area from surgery, the discipline to which it had previously been attached. The competition to run the new department was won by the physician Arnaldo de Moraes in a test that involved checking for cervical lesions through the use of colposcopy (Teixeira, Löwy, 2011; Lana, 2012). Moraes was a gynaecologist of considerable renown. He had specialized at Johns Hopkins University with a scholarship from the Rockefeller Foundation in 1927 and had also worked with Hinselmann in Germany for a time. In the latter post, as well as gaining experience in colposcopy techniques, he enhanced his professional status and strengthened his scientific ties with German science. ${ }^{7}$ In the same year that he joined the faculty, Moraes founded the Anais Brasileiros de Ginecologia and the Brazilian Gynaecology Society. ${ }^{8}$

Moraes's first undertaking at the Faculty of Medicine was the organization of a new clinic for his professorship. It was a conceived as a cutting-edge institution, capable of attracting researchers interested in new diagnostic techniques being developed outside of Brazil. ${ }^{9}$ One of the clinic's main fields of work would be cervical cancer. Planning to study the disease, the gynaecologist João Paulo Rieper arrived at the Institute in 1939. He had previously worked at the Gynaecological Clinic of Berlin University and had also studied colposcopy with Hinselmann. Rieper was recruited by Moraes to introduce the new diagnostic technique at the clinic. He brought with him a colposcopy, the practice of observing the cervix with the instrument and the knowledge concerning the complex classification of the cervical abnormalities identified by Hinselmann (Teixeira, Löwy, 2011). 
In January 1941, Rieper published his first article extolling the value of using colposcopy in the early discovery of cervical cancers. In his conclusions, he proclaimed:

A campaign to educate both the public and physicians is needed, the systematic use of Hinselmann's colposcopy and Schiller's test, the installation of a larger number of easily accessible and free special preventive clinics, and, finally, visiting nurses who ensure continued control of the sick (Rieper, Sthel Filho, 1941, p.77).

In 1942, Rieper published a thesis on the uses of colposcopy in the diagnosis of gynaecological diseases. The same year, Antonio Vespasiano Ramos (1942), another assistant from the Gynaecological Clinic of the Faculty of Medicine, presented a thesis on the use of the Pap smear for early diagnosis of malignant cervical neoplasms. Ramos applied the method described a year earlier by Papanicolaou and Traut (Papanicolaou, Traut, 1941). The combined work of specialists in these different techniques played a key role in shaping the clinic's institutional profile.

The gynaecology clinic expanded rapidly, transforming into a research centre and an outpatient unit for the general public. In 1947 the clinic officially became the Institute of Gynaecology of what was then the Faculty of Brazil, today the Federal University of Rio de Janeiro (UFRJ). To advance the studies of cervical cancer, Moraes and his collaborators set up the Cancer Prevention Outpatient Clinic in the following year. As well as producing research, the latter worked intensely to provide healthcare to women with the disease or suspected of having it. Unlike American and European institutions, which were based on preventing the disease through either cytology or colposcopy, the detection model used by the outpatient clinic combined these two techniques. The "triple model" involved using colposcopy and cytology in all preventive exams. If the gynaecologist observed suspicious lesions during the colposcopy examination, the protocol was for a biopsy of these lesions to be undertaken too (Teixeira, Löwy, 2011). Moraes and his assistants argued that the systematic combination of colposcopy, cytology and biopsy in the outpatient clinic greatly boosted the efficiency in detecting cervical lesions since each technique allowed the observation of different atipias in the cervical cells (Moraes, 1948).

The Institute of Gynaecology (IG) at UFRJ played a leading role in disseminating the prevention model based on the use of colposcopy as a first exam and cytology as a complementary exam (Teixeira, Löwy, 2011). Other institutions, like the Gynaecology Post of the Belo Horizonte Red Cross, created in 1944, the Cervical Cancer Screening Centre of the Institute of Cancer (Rio de Janeiro, 1952) and the Gynaecology Outpatient Clinic of the Ribeirão Preto Faculty of Medicine (1950), would follow the same guideline. The diffusion of the triple model was related to the attempts undertaken by researchers from the IG to institutionalize cytology and colposcopy, evident in the effort made to attract Hinselmann himself to the country and in the assignment of researchers to diverse centres with the objective of training colposcopy technicians and expanding the speciality (Teixeira, Löwy, 2011).

In the 1950s, the group of gynaecologists pioneering the implantation of colposcopy and cytology in the country also worked hard to consolidate their professional field, proving highly productive in publishing articles and organizing technical meetings. ${ }^{10}$ In 1956, 
the gynaecologist Arnaldo de Moraes, head of the Institute of Gynaecology at the Rio de Janeiro Faculty of Medicine, and the physician Clarice do Amaral Ferreira, who had been producing texts on cytology at the same institute, founded the Brazilian Cytology Society (SBC). Two years later, the SBC sponsored the first Brazilian Cytology Symposium. In this same year the Brazilian Colposcopy Society was founded, headed by Clóvis Salgado and Arnaldo de Moraes. Both societies were fundamental in the early institutionalization of cervical cancer prevention practices in the country. The use of the colposcopy-cytology pairing in the discovery of malign cervical abnormalities became the consensus among the gynaecologists. Many of them saw the Pap smear as an additional test to be used when alterations were observed in the colposcopy exam (Teixeira, Löwy, 2011).

\section{From the office to prevention campaigns}

In the 1950s, cervical cancer detection was conducted in gynaecological offices located in universities, local public healthcare institutions and private gynaecological clinics or those partnered with the healthcare services of the pension institutes existing at the time, as well as hospitals and public and philanthropic outpatient units financed by resources from the National Cancer Service. ${ }^{11}$ This care model primarily involved the opportunistic assessment of patients visiting the clinics for diverse reasons who agreed to take the exams to detect any cervical abnormalities. In 1957 ten preventative outpatient clinics existed in Rio de Janeiro (Coutinho, 1957). These services also existed in the capital cities of the more developed states like São Paulo, Bahia and Minas Gerais, many of them receiving funding from the Ministry of Health, transferred by the National Cancer Service. However the range of these initiatives remained severely limited for a long time. According to estimates made by Rieper, Maldonado and Leite (1977), only 11\% of Rio de Janeiro's women in the mid 1970s had access to cervical tumour prevention services.

To extend the coverage of this preventive care, the gynaecologists associated with colposcopy argued for an expansion in the training of physicians specialized in colposcopy. The objective was to transform each gynaecology post into a specialized medical centre for detecting the disease (Salgado, Rieper, 1970). This control model would never come into effect, though, since as the efforts to extend the coverage grew, so the intensive use of colposcopy as a first exam lost ground to the Pap smear, which could be done more quickly at a lower cost. Dispensing with the need for specialist physicians or expensive high-precision equipment, the Pap smear allowed a larger number of women to be screened and facilitated the introduction of mobile clinics and one-off prevention campaigns. ${ }^{12}$

At the start of the 1960s, a number of cervical cancer detection campaigns were launched based on the use of the Pap smear on a large scale. The strategy now was not to conduct exams on women visiting health clinics in relation to other problems. The aim rather was to encourage healthy women to visit the clinics to perform the test or even to take the tests to them. In Rio de Janeiro in 1957, the Social Pioneers Foundation had inaugurated the Luiza Gomes de Lemos Research Centre, promoting studies in the field of gynaecology. ${ }^{13}$ An outpatient clinic for cervical cancer prevention was opened at the centre: this began to organize mobile disease prevention campaigns, based on a fleet of mobile health units 
that operated in Rio de Janeiro. The Social Pioneer Women played a prominent role in controlling the cancer. As well as formulating campaigns in diverse areas in partnership with other institutions, they worked to train technical staff to implement these initiatives. Their cytotechnical training school, created in 1968, as well as pioneering, served as a model for training these professionals in Brazil (Teixeira, Porto, Souza, 2012; Temperini, 2012).

In Bahia, the Aristides Maltez Hospital, founded by the Bahian League Against Cancer, also successfully developed campaigns against cervical cancer. Initially its work was conducted on the same bases as the other outpatient clinics already described above, including the use of colposcopy as an initial exam for identifying lesions. In 1955 the search to broaden its area of activity led the hospital to set up provisional clinics to examine women in the countryside of the state, opting to use the Pap smear as a primary method and colposcopy used when further clarification was needed. The tests were conducted in the regional clinics and analysed at the hospital's main unit in Salvador. From the mid 1960s, the external work of the Aristides Maltez Hospital was expanded with the establishment of a network of smear collection centres in the municipalities of the Recôncavo region of Bahia. These centres operated intermittently, developing specific disease prevention campaign (Lana, 2012, p.213).

During the 1960s and early 1970s, cervical cancer prevention initiatives continued to expand. Prevention services in public hospitals, universities, health departments, preventative outpatient clinics sponsored by leagues against the disease and a number of campaigns became included in the scenario for controlling the disease. For their part, the gynaecologists and cancerologists increasingly perceived cervical cancer as a public health issue, advocating the amplification of initiatives for its control, particularly in the more remote regions of the country.

In the mid 1970s, the utilization of exfoliative cytology as an initial test to detect cervical cancer was already a point of consensus among the medical community. The stabilization of the technique at international level, the possibility of expanding coverage more effectively because of the relative speed of the test, and the advances made by the programs that emerged in diverse states all helped disseminate the Pap smear. The medical interest in intensifying prevention of the disease by expanding use of the test was so strong that between 1970 and 1973 gynaecologists from the National Institute of Cancer (INCA), supported by leagues for combatting cervical cancer and the National Cancer Service itself, drafted a law bill to make the Pap smear compulsory for women over the age of the $23 .{ }^{14}$ Although this bill never became law, it revealed just how important the prevention of the disease had become as an issue, since until that moment compulsory forms of preventative medicine had been limited to transmissible diseases. Later, when gynaecologists who identified with this proposal obtained important positions in the public health system, the actions direct to cervical cancer took a central role in the area of cancer control.

\section{The expansion of screening}

At the beginning of the 1970s, the transformations in international healthcare reflected a greater awareness of the value of prevention and primary care, especially in less developed countries. In Latin America, this directive was led by the Pan American Health Organization 
(PAHO) and combined with increased attention to planning healthcare initiatives, as well as combating poverty-related health issues, like transmissible and avoidable diseases. ${ }^{15}$ In the area of Brazilian medical opinion, both the reformist ideas of the sanitaristas, who decades later would lead the health sector reform, and the thinking of the groups responsible for coordinating the Ministry of Health's policies agreed on the need to extend healthcare coverage to needy populations and to broaden the range of basic health initiatives. ${ }^{16}$ In this context, cervical cancer was transformed into a target for broader public healthcare intervention and was included on the agenda of federal and local governments, as well as philanthropic institutions, through screening campaigns.

The first public screening programs for cervical cancer had appeared in the USA and Europe in the 1950s (Löwy, 2010). In the 1960s, PAHO identified the disease as a serious but controllable public health problem in Latin American countries, proposing the introduction of screening campaigns. This position coincided with the opinion of Brazilian specialists who saw the more comprehensive campaigns as the best way to control the disease.

As we have seen, a variety of prevention campaigns were introduced across the country during this period. The pioneer example was the Campinas Cervical Cancer Control Program in São Paulo state, launched in 1965 at the Department of Gynaecology and Obstetrics of Campinas State University and headed by the physician José Aristodemo Pinotti. He had specialized in gynaecology in Europe and possessed a keen interest in public healthcare initiatives focused on women's health. With the technical assistance of, PAHO, Pinotti implemented a program intended to provide a permanent solution to preventing the disease in the Campinas region (Pinotti, Zeferino, 1987).

The program used the Pap smear as the first examination for all women screened and was innovative in various aspects. To speed up the collection of samples, healthcare professionals without medical training were employed. The tests were conducted in diverse units, such as municipal and state health clinics, allowing a higher number of women to be tested. The analysis of the slides was centralized in a laboratory especially created for the purpose. The program also invested in training cytotechnicians to analyse the slides. Working in collaboration with municipal and state health departments, hospitals and other philanthropic medical institutions, the program developed an innovative methodology for preventing cervical cancer (Pinotti, Zeferino, 1987).

Other initiatives from São Paulo state followed the path opened up by the Campinas program. In 1967, the São Camilo Gynaecological Cancer Prevention and Treatment Institute was created at the philanthropic São Camilo Hospital. The centre was coordinated by gynaecologist Sampaio de Góes, who years later would head the Cancer Control Division of the Ministry of Health, operating with funds from philanthropic sources and the state of São Paulo. ${ }^{17}$ Also in association with the state government, Góes founded the Brazilian Institute of Studies and Research in Obstetrics and Gynaecology (IBEPOG) in 1968. The institute was a private enterprise that also received funds from the São Paulo state government, and comprised the state's leading centre for studying cervical cancer and formulating actions towards its prevention and treatment.

From the 1970s onwards, IBEPOG organized various initiatives to control cervical cancer in São Paulo state. In 1970 a campaign was launched to combat the disease in the city of 
São Caetano do Sul. Adopting the paradigm developed by the Campinas program, it also employed paramedical staff to collect samples and guaranteed hospital treatment of patients where necessary. During its first three years, the São Caetano program reached 51,227 women through advertising campaigns and active searching. Positive smears were investigated at a medical centre set up by the local municipal council and clinical cases were forwarded to cancer hospitals in the state (Capucci, 2003).

In 1975, the state of São Paulo implanted a state-wide cervical cancer prevention program based on its early experiences in the city and the work conducted by Pinotti in Campinas. The program was permanent one and organized by the Foundation Centre for Oncological Research (FCPO) created by Sampaio de Góes in 1974 and directed by himself. The program included state and municipal health clinics, some private medical practices and even a number of mobile units (a bus and various train carriages) that functioned as a support base for collecting smears. The slides were analysed at the FCPO, while treatment and surgery were carried out at the Brazilian Cancer Control Institute, a private hospital created by Góes and ran with state government funding (Capucci, 2003). Later a new program was set up to cover the east zone of São Paulo city (Goes Júnior et al., 1979).

In 1972, Sampaio de Góes became director of the National Cancer Division of the Ministry of Health. The National Cancer Control Program (PNCC) was created during his administration. Designed to broaden actions to combat cancer in a planned form, the program's budget was included in the Second National Development Plan. ${ }^{18}$ Based on a mapping of the installations and equipment used to treat cancer across the country, a plan was developed to equip the public and private healthcare units. The program gave special attention to the development of initiatives to prevent cervical cancer. Receiving funds from an agreement with PAHO, it financed courses to train cytotechnicians, promoted the standardization of patient records and assisted the screening campaigns conducted by state health departments, cancer hospitals and civil institutions (Lago, 2004). The PNCC also instituted the reimbursement of all cancer-related procedures performed by private hospitals and laboratories. This measure was intended to stimulate the interest of professionals working in private medicine in preventative actions to combat the disease and, according to some of those working in the area, would prove to be of considerable importance in disseminating the Pap smear. ${ }^{19}$

With the advent of the PNCC, cervical cancer became included in the Ministry of Health's policy agenda. In 1975 the disease would fall under the remit of the Ministry of Social Welfare following the creation of its Cancer Control Program (PCC), in operation between 1976 and 1980. The PCC was formulated to link the prevention and treatment offered by private medicine with the network of public-sector outpatient clinics and hospitals. Its main legacy was the formal universalization of procedures for controlling cancer as part of the country's Social Welfare, in theory assuring every citizen the right to free treatment of the disease (Teixeira, Porto, Noronha, 2012).

Following the economic crisis that hit the country at the end of the 1970s and the frequent changes in health policy directives, cervical cancer lost its central place on the national health policy agenda. The exclusion of the PNCC from the Third National Development Plan (Third PND, 1980) meant the end of specific funding to control cancer, impeding the development 
of diverse campaigns and programs. The disease reverted to being conceived as a routine activity covered by the policy programs of the Ministries of Health and Social Welfare. The main legacies of the PNCC and the PCC were the development of the concept of integrated planning as a form of controlling the disease and the attempt to extend the coverage of actions to combat the disease (Teixeira, Porto, Noronha, 2012). Despite its institutional importance, in the mid 1980s the control of cervical cancer in Brazil was still in its early stages, presenting far from promising results. A survey conducted by the National Institute of Cancer (INCA) in 1984 showed that, at the time, just 7\% of the basic healthcare units run by the state health departments conducted cytological tests. In the area of private medicine, no information was available on the frequency of these examinations, though a calculation based on visits to gynaecologists indicated that less than $16 \%$ of Brazilian women over the age of 15 had been given the test (Aquino et al., 1986).

\section{National actions and campaigns to control cervical cancer}

From the second half of the 1970s onwards, cervical cancer became defined as a public health problem stemming from the inequalities in Brazil's social organization. Brazilian specialists increasingly related the higher frequency of cervical cancer with the early start to sexual life, the existence of multiple sexual partners, early pregnancy, lack of hygiene and poor nutrition (Pinotti 1976; Giordano, Casanova, 1976; Martins et al., 1976). At the end of the decade, the works showing the association between HPV infection and cervical cancer led to the classification of cervical cancer as a sexually transmitted disease. ${ }^{20}$ The discovery of the role of HPV in the emergence of cervical cancer reinforced the disease's relation to the living conditions of more disadvantaged social groups and served as the basis for formulating broader actions against the disease.

In the public policy area, the expansion of state actions to prevent cervical cancer reflected the growing force of women's movements campaigning for better healthcare. These demands resonated even more emphatically in the context of the country's return to democracy, enabling the introduction of a Comprehensive Women's Health Program (PAISM) in 1984 under the coordination of the Ministry of Health. ${ }^{21}$ PAISM's creation reflected government concerns with controlling the birth rate control. Following the pressure from social movements, however, the program's scope was widened to include actions directed towards family planning, better healthcare for women in the public system and the control of the most prevalent diseases among this group (Osis, 1998). One of the targets of these actions was cervical cancer, which, after PAISM was introduced, began to receive greater attention from the Ministry of Health with the intensification of educational actions and initiatives to make the Pap smear more widely available (Pinho, 2003).

Despite these initiatives, it was only with the new constitutional text of 1988 and the creation of the National Health System (Sistema Único de Saúde - SUS) that the policies designed to control cervical cancer would take a new direction. By establishing healthcare as the citizen's right and the State's duty, unifying the public and private healthcare sectors, as well as emphasizing the importance of preventive actions, the Ministry of Health obtained an institutional framework for undertaking more comprehensive action in the area 
of public health. Specifically in terms of controlling cervical cancer, the biggest institutional change would be the introduction of a national cervical cancer screening program.

In the mid 1990s, the question of women's health was high on the agenda. In October 1995 the sixth International Women's Conference assembled thousands of women from across the planet to discuss questions related principally to the conditions of the world's poorest women. Brazil's participation was carefully organized by civil and governmental institutions, assisted by more than eight hundred women's groups. The conference included the involvement of more than three hundred Brazilian women. The official delegation, comprising 25 members and headed by the then president's wife, Ruth Cardoso, fulfilling the agenda formulated jointly with social movements, agreed to take measures to reduce the alarmingly high rates of death from cervical cancer at the time (Espírito Santo, 1 jun. 2012; Thuler, 9 out. 2010).

By this point, thanks to healthcare reform, INCA had become the reference centre in oncology for the SUS. It had incorporated the National Oncology Program (PRO-ONCO) and had been highly active in the areas of information, education and prevention in relation to diverse types of cancer, working in partnership with state and municipal health departments, cancer services and hospitals, universities and civil society sectors (Abreu, 1997). In order to implement the directive signed by Brazil in Beijing in 1997, INCA introduced a cervical cancer screening project which would function as a pilot for the creation of a national program to control the disease. Named Viva Mulher (Long Live Women) on its launch, the project was implanted in six localities: Belém (Pará), Curitiba (Paraná), Brasília (in the regions of Tabatinga, Ceilândia and Samambaia, as well as the Federal District), Recife (Pernambuco), the west zone of Rio de Janeiro city (Rio de Janeiro), and the state of Sergipe. The goal was to expand access to cytopathological exams, prioritizing women at greater risk and ensuring their reception, as well as the appropriate treatments of the cancer and precursor lesions in $100 \%$ of cases (Brazil, 2011).

In August 1998, the Ministry of Health decided to take on full responsibility for the project's execution, transforming it into a nationwide campaign coordinated by the Public Policy Department of the Ministry of Health. The campaign's targets were: to: collect samples for cytological examination from 70\% of women aged between 35 and 49 years old who had never taken the exam; guarantee that all exam results would be returned to the women more or less within one month; and monitor all women with a positive cytology result until the completion of treatment (Lago, 2004). However a variety of problems prevented these objectives from being attained. Among the main problems observed were the unpreparedness of the healthcare system to deal with the large influx of women responding to the call for them to take the exam, the inefficiency of the electronic information system, the incapacity of institutions and professionals to analyse the slides and the difficulties faced by some of the women obtaining a positive result (Thuler, 9 out. 2010).

In April 1999, Viva Mulher reverted to INCA's control. INCA mounted another largescale campaign in 2002, prioritizing those women aged between 35 and 49 who had yet to undertake the preventative exam or who had last received a Pap smear more than three years ago. According to the institute, more than 3.8 million women were examined during this second campaign. ${ }^{22}$ After evaluating the results, INCA's specialists concluded that the cervical cancer control policy should be based on routine cytological exams and Viva Mulher 
was transformed into a permanent cervical cancer screening program at the national level (Brazil, 2002).

The Viva Mulher program continued to function, focusing its priorities on improving the network of oncological care by providing technical support to the Brazilian states, technological modernization of the information system and review of the indicators used to monitor the program's actions (Brazil, 2002). Despite the problems observed in the initial campaigns and the lack of epidemiological data to verify their effectiveness, they were successful in increasing the use of the Pap smear, which showed a 81\% growth in the annual number of tests registered by the SUS between 1995 and 2003 (Lago, 2004).

\section{Final considerations}

As I observed at the start of this paper, despite the progress made in disseminating preventive measures, cervical cancer remains a major health problem in Brazil. The persistence of the disease, especially in poorer regions of the country, reveals - aside from the obvious difficulties posed by living conditions - the lack of adequate organization of the health system and its limitations in terms of regional disparities. Moreover, it reflects the slow and uneven historical incorporation of sectors of Brazil's population into public health concerns and the relation between this process and technico-scientific development.

The first healthcare initiatives aimed at cervical cancer related to the development of techniques for preventing the disease and merely reached the small number of women who frequented private medical practices or who, for diverse health reasons, used the gynaecological services at university or philanthropic institutions. The standardization of the prevention technique on a large scale and the growing concern with cervical cancer at international level - through the work of agencies like PAHO - allowed the first campaigns to become established. The redefinition of cervical cancer as a poverty-related disease and subsequently as a sexually transmitted disease, following the discovery of the role of HPV in its transmission at the end of the 1970s, was of considerable importance in terms of constructing a national policy for the disease's control. The cancer became increasingly visible as a problem during a period when women's health issues, especially the problems faced by poorer women, were highlighted through the actions of organized social movements, whose demands became heard on the international health agenda. The unification of the health system with the healthcare reform undertaken at the end of the 1980s enabled the creation of a wide-ranging campaign to screen for the disease, later transformed into a permanent national program.

Although the organization of screening programs had succeeded in lowering cervical cancer rates in diverse countries, in Brazil the reality proved to be different. ${ }^{23}$ Although Viva Mulher widened use of the Pap smear, the mortality rates associated with the disease remained similar to the levels recorded before the program's introduction, demonstrating additional difficulties for its control. ${ }^{24}$ Various aspects merge in this context, a central element being the exam's area of coverage. This varies considerably with less populated regions containing areas with lower organization of health services, such as the North and Centre-West, presenting lower coverage of tests and higher cervical cancer rates. Furthermore, the Pap smear reached an 
average of less than 70\% of the female population in 2003 (Martins, Thuler, Valente, 2005). This rate is still low, given that studies by the World Health Organisation emphasize the need for the screening to cover around $80 \%$ of the vulnerable population in order for associated mortality rates to drop (Martins, Thuler, Valente, 2005).

As well as the difficulties in accessing the system, the low development index of diverse groups and locations hinders further expansion of the Pap smears. Women with little schooling, low family income and a young age are the least likely to accept screening. The lack of knowledge about the exam and the disease, combined with fears related to the difficulty of the treatment if the disease is discovered, mean that the women very often avoid the campaigns. ${ }^{25}$ Other aspects, such as the gynaecological nature of the exam itself, the anticipated embarrassment of the test being performed by men, the unpreparedness of the health professionals in dealing with the women, the stigma associated with the disease, the fact that its risk factors include patterns of sexual behaviour, and the fear that the exam might reveal the existence of sexually transmitted diseases, are related more generally to the difficulties in expanding use of the Pap smear (Cruz, Loureiro, 2008).

Another difficulty faced in controlling cervical cancer in Brazil is the quality of the exams. Some studies have shown the difficulty of evaluating the quality of the exams undertaken due to the lack of information on the private laboratories that provide the service to the public health system. This problem is compounded by the absence of specific legislation to guarantee the monopoly on analysing slides in adequate situations to qualified cytotechnicians. ${ }^{26}$ The failure to regulate the work of cytotechnicians places at risk the quality of the exams undertaken in the country, enabling the emergence of dangerous false negatives, which can determine the development of the disease in women covered by the system.

These aspects reflect some of the difficulties of scientific and technical development and policies when it comes to controlling cervical cancer in Brazilian society. However in addition to Brazil's highly diverse socioeconomic and cultural patterns, which hinder the homogenization of the supply and uptake of the exam, observing the profile of the country's health system and its historical development are crucial in terms of understanding the difficulties faced in controlling cervical cancer. Here the tension between the public and the private proves central. Although the country has possessed a public and universal health system for over two decades, which supports the cervical cancer control program at national level, it also has a powerful private health sector that reaches around $25 \%$ of the population, mainly through private healthcare insurance. These plans, which cover the population with greater purchasing power, are little regulated in terms of their practices and provide varying levels of care to their customers. ${ }^{27}$

This configuration of the health system has led to the emergence of two different regimes for controlling cervical cancer in the country. Poorer women carry out their preventive tests at public health clinics: following the guidelines of international agencies, these involve three consecutive annual exams and, if no problems are detected, new exams must be taken every three years between the ages of 25 and 64. Middle and upper class women, who typically have health insurance plans or frequent private medical practices, usually undertake preventative exams every year, regardless of the sequence of negative smears. This situation leads to the paradox of women at less risk of contracting the disease undertaking more tests than those 
at greater risk (Teixeira, Löwy, 2011). Moreover, as Moraes et al. (2011) point put, women with health plans, irrespective of their socioeconomic and cultural situation, have a $26.1 \%$ higher chance of conducting Pap smears than women covered by the SUS program.

In recent years, the discussion on whether to add the HPV vaccine to the list of vaccines freely distributed by the public health system has animated a large number of specialists. This debate was also connected to questions linked to the tension between the public and private sectors of the Brazilian health system. While the experts discussed the vaccine's potential effectiveness given the specificities of the country's social context and its costs for the public health system, pressure groups lobbied for the State to include the vaccine in its portfolio of services, pointing out that it had been purchased at high prices from private clinics by the wealthier sectors of the population over recent years.

In 2013, the SUS include the HPV vaccine in its list of freely available vaccines (Brazil, 18 Nov. 2013), beginning to distribute it to Brazilian girls in March 2014. This initiative revives hopes for changes in cervical cancer control in the country, anticipating that its widespread use may reduce the problems concerning the coverage and quality of the Pap smear. Nonetheless, specialists warn that the creation of a vaccination program does not by itself guarantee control of the disease, since its use may end up limited to groups at lower risk - recognizing that the populations at higher risk very often live in isolated localities in survival conditions and cultural realities that impede uptake of the vaccine. ${ }^{28}$ On this point too, the practical results of our technoscience are focused on the local specificity of our social organisation.

\section{NOTES}

${ }^{1}$ With the exception of non-melanoma skin cancer, breast cancer has the highest incidence among Brazilian women. In relation to total mortality rates, the most lethal diseases are breast cancer (16\%), followed by cancers of the tracheas, bronchi and lungs (10\%), colon and rectum (8.6\%) and cervix (6.6\%) (Brazil, 2011).

${ }^{2}$ The colposcopy exam involves the visual observation of the cervix with the help of an optical instrument called the colposcope. Areas of the cervix with particular alterations may indicate the existence of lesions that can tranform into cancer.

${ }^{3}$ In 1915, the physician Fernando Magalhães advocated the use of mesothorium (an isotope of radium, discovered in 1905) as a better form of treating the disease.

${ }^{4}$ On the development of social concerns over cancer, see the pioneering work of Patrice Pinel (1992).

${ }^{5}$ Gouveia (1938, p.524) provided the example of Switzerland, where leaflets were produced using simple language to explain the initial symptoms of the disease and the need to go to a doctor straight away. These leaflets were distributed in outpatient clinics, factories, proletarian meetings, hospitals, class associations, professional schools for female students, schools and so on.

${ }^{6}$ On the German and French medical-scientific movement and its influence on Latin America, especially Brazil, see Sá et al. (2009). On the migration of colposcopy to Latin America, see Eraso (2010).

${ }^{7}$ The prestige achieved by Moraes among German gynaecologists can be ascertained by his obituary, published in the journal Zentralblatt für Gynäkologie. The text emphasizes that with his death German gynaecology had lost a loyal friend of considerable scientific, medical and human aptitude (Nekrolog, 1961, p.1701).

${ }^{8}$ The Anais Brasileiros de Ginecologia became the Jornal Brasileiro de Ginecologia in 1970.

${ }^{9}$ The clinic moved to the Estácio de Sá Hospital, where it remained until 1942, when it was transferred to the Moncorvo Filho Hospital, where the Institute of Gynaecology still functions today (Lana, 2012).

${ }^{10}$ In a recent doctoral thesis, the historian Vanessa Lana (2012) argues that the Institute of Gynaecology of the University of Brazil, the Institute of Belo Horizonte and the Aristides Maltez Hospital together formed a network for exchanging information and practices in the dissemination of cervical cancer prevention in Brazil. 
${ }^{11}$ The Brazilian policy for controlling cancer began with the creation of the National Cancer Service (SNC), em 1942. The SNC was formed by the Institute of Cancer (today INCA) and the National Campaign Against Cancer, a network of state or philanthopic hospitals and civil institutions - leagues - that, receiving financial aid from the federal government, either provided care to the sick or produced and distributed educational propaganda. The work of the National Institute of Cancer, in the Federal District, the actions at regional level carried out in hospitals affiliated with the Campaign, and the propaganda initiatives carried out by the leagues, with the help of the SNC, constituted the general profile of the cancer control policy in Brazil between 1940 and 1960 (Teixeira, 2009).

${ }^{12}$ Though precise information on the price of colposcopy devices is lacking, the sources researched mention their high cost at times and indicate the fact that they were imported, the best being German-made (produced by the Carl Zeiss company). Rieper (1955) adds that the cheaper instruments had an inferior performance.

${ }^{13}$ The Social Pioneers Foundation was created in 1956 by Sarah Kubitschek - wife of the then governor of Minas Gerais, Juscelino Kubitschek (who would later be president of the Republic between 1955 and 1960) with the objective of implementing social works providing care to children and women in need. In the 1970s, the Foundation was transformed into a large institution, maintaining educational and preventative medicine initiatives in a large number of states (Temperini, 2012).

${ }^{14}$ In 1970, the São Paulo Association for Combating Cancer sent a petition to the minister of Work requesting the inclusion of the Pap smear in the compulsory medical exam for admission to public employment. This petition spent a long time being processed by the Ministry of Work. In 1973 the gynaecologist Alberto Coutinho of the National Institute of Cancer revived the proposal and, with the consent of the director of the National Division of Cancer, forwarded it to the Ministry of Health. The issue now was to make the test certificate a compulsory document for a variety of activities, such as the admission to public and private jobs, obtaining documents, loans, etc. A law bill was even elaborated by Coutinho himself and presented to the minister. However, after many discussions, the bill was abandoned after being considered unviable (Brazil, n.d.).

15 The diagnoses carried out under the patronage of PAHO and WHO showed a worrying health situation in Latin America, which combined low healthcare coverage with the spread of poverty-related diseases (Cueto, 2007).

${ }^{16}$ The 1970s marked the first steps of the movement for health reforms that culminated in the healthcare reform of 1988. Under the slogans of "health and democracy" and "health for all," a multifaceted group of sanitaristas and other professionals from the medical area joined forces in institutions and initiatives with the aim of instigating a reform process that extended public health coverage and ended the division between private and public healthcare.

17 The São Camilo Institute for the Prevention and Treatment of Gynaecological Cancer was created in 1967 via an agreement with the Health Department of the State of São Paulo, which included the transfer of funds and the inclusion of two physicians from the department in the program's team to act in the prevention and treatment of gynaecological cancer.

${ }^{18}$ According to the initial bill, the program would have a budget of 220 million cruzeiros (Capucci, 2003), 37 million dollars at the time.

${ }^{19}$ Information on the importance of public funding for the Pap tests carried out in the private healthcare system as part of the expansion of testing are contained in the testimony given by Edmur Flavio Pastorello (20 mar. 2010) to the oral history program of the cancer history project.

${ }^{20}$ In 1975 the German infectologist Harald zur Hausen postulated that cervical cancer was associated with a virus related to the appearance of genital warts. In 1977 his studies identified HPV as the agent involved in this association. At the start of the 1980s, Hausen and his collaborators demonstrated that strains 16 and 18 of HPV were associated with the disease (Löwy, 2011).

${ }^{21}$ According to Osis (1994), the concept of comprehensive women's healthcare, which formed the basis of PAISM, emerged from the biomedical area of Unicamp - which as we saw created a permanent cervical cancer control program - in its critique of the vertical health programs aimed at specific problems and target publics.

${ }^{22}$ On the trajectory of Viva Mulher, see: http://www.redecancer.org.br/wps/wcm/connect/cancercoloutero/ site/home/historico_programa++/historico.

${ }^{23}$ According to Gustafsson et al. (1997), the cervical cancer incidence rate was heavily reduced in 11 of the 17 countries observed by them, varying from $27 \%$ in Norway to $77 \%$ in Finland. 
${ }^{24}$ According to Martins, Thuler and Valente (2005, p.486), "The adjusted mortality rates for cervical cancer are still moderately high in the country and, in temporal terms, have remained stable: in 1979, the rate was 4.97/100,000, while in 2002 it was 5.03/100,000, corresponding to a relative percentage variation of $1.2 \%$."

${ }^{25}$ Fernandes at al. (2009, p.855), focusing on the Northeast of Brazil, state that: "Women from the urban area, middle class, those with better education, the unmarried, and those who use some form of contraception, presented better understanding of the test's purpose. This can be explained by the greater access to information on the test and more opportunities to take it."

${ }^{26}$ On the laboratories producing cytological exams, see Thuler, Zardo and Zeferino (2007). An analysis of the training of cytotechnicians in Brazil can be found in Teixeira, Porto and Souza (2012).

27 The private healthcare sector offers outpatient and hospital services paid by direct disbursement or through private health plans and insurance. According to Paim et al. (2011), in 1998, 24.5\% of the Brazilian population possessed health insurance. This proportion had risen to $26 \%$ in 2008.

${ }^{28}$ Testimony of Luiz Carlos Zeferino (7 May 2012) to the cancer history project.

\section{REFERENCES}

ABREU, Evaldo.

Editorial: Pro-onco 10 anos. Revista Brasileira de Cancerologia, v.43, n.4, p.237-238. 1997.

AQUINO, Estela Maria L. et al.

Situação atual da detecção precoce do câncer cérvico-uterino no Brasil. Cadernos de Saúde Pública, v.2, n.1, p.53-65. 1986.

BRASIL.

Ministério da Saúde. Portaria n.54. Torna pública a decisão de incorporar a vacina quadrivalente contra HPV na prevenção do câncer de colo do útero no Sistema Único de Saúde. Disponível em: http://bvsms.saude.gov.br/bvs/saudelegis/ sctie/2013/prt0054_18_11_2013.html. Acesso em: 25 jul. 2014.18 nov. 2013.

BRASIL.

Ministério da Saúde. Instituto Nacional de Câncer. Estimativa 2012: incidência de câncer no Brasil/Instituto Nacional de Câncer. Rio de Janeiro: Inca. Disponível em: http://bvsms. saude.gov.br/bvs/publicacoes/abc_do_cancer.pdf. Acesso em: 25 jul. 2014. 2011.

BRASIL.

Ministério da Saúde. Secretaria de Assistência à Saúde. Instituto Nacional do Câncer. Viva Mulher. Câncer do colo do útero: informações técnico-gerenciais e ações desenvolvidas. Rio de Janeiro: Inca. 2002.

BRASIL.

Ministério da Saúde. Arquivo do Ministério da Saúde; caixa 569, maço 2402-2496

(Coordenação Regional do Arquivo Nacional, Distrito Federal). s.d.

CAPUCCI, Fatima.

Filosofia Sampaio Góes: Instituto Brasileiro de Controle do Câncer (IBCC), 35 anos. São Paulo: Activa Comunicação. 2003.
CASPER, Monica; CLARKE, Adele.

Making Pap smear into the "right tool" for the job: cervical cancer screening in the USA, circa 1940-1995. Social Studies of Science, v.28, n.2, p.255-290. 1998.

COUTINHO Alberto.

A educação na luta contra o câncer. Revista Brasileira de Cancerologia, v.14, n.17, p.5-63. 1957.

CRUZ, Luciana Maria Britto da; LOUREIRO, Regina Pimentel.

A comunicação na abordagem preventiva do câncer do colo do útero: importância das influências histórico-culturais e da sexualidade feminina na adesão às campanhas. Saúde e Sociedade. v.17, n.2, p.120-131. 2008.

CUETO, Marcos.

O valor da saúde: história da Organização Panamericana da Saúde. Rio de Janeiro: Fiocruz. 2007.

ERASO, Yolanda.

Migrating techniques, multiplying diagnoses: the contribution of Argentina and Brazil to early "detection policy" in cervical cancer. História, Ciências, Saúde-Manguinhos, v.17, supl.1, p.33-51. 2010.

ESPÍRITO SANTO, Maria do.

[Depoimento]. Entrevistadores: Marco Porto Laurinda Maciel, Paula Habib. Rio de Janeiro: Casa de Oswaldo Cruz. Meio digital (2h55min). Depoimento concedido ao projeto História do câncer: atores, cenários e políticas públicas. 1 jun. 2012.

FERNANDES, José Veríssimo et al. Conhecimentos, atitudes e prática do exame de Papanicolaou por mulheres, Nordeste do Brasil. Revista de Saúde Pública, v.43, n.5, p.851-858. 2009.

GIORDANO, Caetano; CASANOVA, Rubens. Aspectos epidemiológicos do carcinoma do colo 
uterino. Jornal Brasileiro de Ginecologia, v.81, n.2, p.71-78. 1976.

GOES JÚNIOR, João Sampaio et al.

Primeiros achados sobre detecção e prevenção do câncer uterino no projeto Zona Leste, São Paulo. Ginecologia Brasileira, v.3, n.9, p.89-90. 1979.

GOUVEIA, Nabuco.

Comunicação à Sociedade Brasileira de

Ginecologia. Brazil Medico, v.6, n.3, p.526. 1938.

GREGG, Jessica L.

Virtually virgins: sexual strategies and cervical cancer in Recife, Brazil. Stanford: Stanford University Press. 2003.

GUERRA, Maximiliano Ribeiro et al. Risco de câncer no Brasil: tendências e estudos epidemiológicos mais recentes. Revista Brasileira de Cancerologia, v.51, n.3, p.227-234. 2005.

GURGEL, Nascimento.

Comunicação à Sociedade Científica Protetora da Infância em 30 de maio de 1903. Brazil Medico, v.17, n.23, p.412. 1903.

GUSTAFSSON, Leif et al.

International incidence rates of invasive cervical cancer after introduction of cytological screening. Cancer Causes Control, v.8, n.5, p.755-763. 1997.

HAKAMA, Matti et al.

Evaluation of screening programes for gynaecological cancer. British Journal of Cancer, v.4, n.52, p.669-673. 1985.

LAGO, Tânia Di Diacomo do.

Políticas nacionais de rastreamento do câncer de colo uterino no Brasil: análise do período 19982002. Tese (Doutorado) - Instituto de Filosofia e Ciências Humanas, Universidade Estadual de Campinas, Campinas. 2004.

LANA, Vanessa.

Ferramentas, práticas e saberes: a formação de uma rede institucional para a prevenção do câncer de colo de útero no Brasil, 1936-1970. Tese (Doutorado) - Programa de Pós-graduação em História das Ciências e da Saúde, Casa de Oswaldo Cruz, Fiocruz, Rio de Janeiro. 2012.

LATOUR, Bruno.

Reagregando o social: uma introdução à teoria do ator-rede. Salvador: Edufba; Bauru: Edusc. 2012.

LÖWY, Ilana.

A woman's disease: the history of cervical cancer. New York: Oxford University Press. 2011.

LÖWY, Ilana.

Preventive strikes: women, precancer, and prophylactic surgery. Baltimore: The Johns Hopkins University Press. 2010.
MAGALHÃES, Fernando.

O mesothorio no tratamento do cancro uterino. Brazil Medico, v.29, n.5, p.41-42. 1915.

MARTINS, Luís Felipe Leite; THULER, Luiz Claudio Santos; VALENTE, Joaquim Gonçalves. Cobertura do exame de Papanicolaou no Brasil e seus fatores determinantes: uma revisão sistemática da literatura. Revista Brasileira de Ginecologia e Obstetrícia. v.27, n.8, p.485-492. 2005.

MARTINS, Nelson V. et al.

Prevenção do câncer ginecológico: estudo sócioeconômico, colposcópico e citohistológico. Jornal Brasileiro de Ginecologia, v.81, n.4, p.185-187. 1976.

MORAES, José Rodrigo de et al.

Relação entre plano de saúde e a realização do exame Papanicolaou: uma aplicação de escore de propensão usando um inquérito amostral complexo. Revista Brasileira de Epidemiologia, v.14, n.4, p.589-597. 2011.

MORAES, Arnaldo de.

Consultório preventivo de câncer ginecológico. Anais Brasileiros de Ginecologia, v.25, n.3, p.47-49. 1948.

NEKROLOG.

Zentralblatt fur Gynäkologie, v.83, n.43, p.1701. 1961.

OSIS, Maria José Martins.

Paism: um marco na abordagem da saúde reprodutiva no Brasil. Cadernos de Saúde Pública, v.14, supl.1, p.25-32. 1998.

OSIS, Maria José Martins.

Atenção Integral à Saúde da Mulher, o conceito e o programa: história de uma intervenção. Dissertação (Mestrado) - Departamento de Antropologia Social, Instituto de Filosofia e Ciências Humanas, Universidade Estadual de Campinas, Campinas. 1994.

PAIM, Jairnilson et al.

O sistema de saúde brasileiro: história, avanços e desafios. The Lancet, v.377, n.9779, p.1778-1797. 2011.

PAPANICOLAOU, George; TRAUT, Herbert. The diagnostic value of vaginal smears in carcinoma of the uterus. American Journal of Obstetrics and Gynecology, n.42, p.193-206. 1941.

PASTORELLO, Edmur Flávio.

[Depoimento]. Entrevistador: Luiz Antonio Teixeira. Rio de Janeiro: Casa de Oswaldo Cruz. Meio digital (2h10min). Depoimento concedido ao programa de história oral do projeto História do câncer: atores, cenários e políticas públicas. 20 mar. 2010. 
PINELL, Patrice.

Naissance d'un fléau: histoire de la lutte contre le cancer en France (1890-1940). Paris: Métailié. 1992.

PINHO, Adriana de Araujo.

Prevenção do câncer de colo do útero: um modelo teórico para analisar o acesso e a utilização do teste de Papanicolaou. Revista Brasileira de Saúde Materno-Infantil, v.3, n.1, p.95-112. 2003.

PINOTTI, Jose Aristodemo.

Experiência crítica do controle de câncer cérvicouterino de Campinas, Brasil. Jornal Brasileiro de Ginecologia, v.82, n.4, p.461-471. 1976.

PINOTTI, Jose Aristodemo; ZEFERINO, Luiz Carlos.

Programa de controle de câncer cérvico uterino. Campinas: Editora da Unicamp. Série saúde da mulher. 1987.

RAMOS, Antonio Vespasiano.

Novo método de diagnóstico precoce do câncer uterino. Tese (Doutorado) - Faculdade Nacional de Medicina, Universidade do Brasil, Rio de Janeiro. 1942.

RIEPER, João Paulo.

Como fazer o exame colposcópico. Anais

Brasileiros de Ginecologia, v.40, n.3, p.207-212. 1955.

RIEPER, João Paulo.

Sobre o valor prático da colposcopia: estudos baseados em 1100 observações. Tese (Doutorado) - Instituto de Ginecologia, Universidade do Brasil, Rio de Janeiro. 1942.

RIEPER, João Paulo; MALDONADO, Helia; LEITE, Eduardo José Campos.

Inquérito sobre as atividades de prevenção do câncer do colo uterino no Rio de Janeiro, 1975. Ginecologia Brasileira, v.1, n.9, p.131-134. 1977.

RIEPER, João Paulo; STHEL FILHO, J.C. Considerações sobre frequência, diagnóstico e tratamento de câncer nos últimos 4 anos. Anais Brasileiros de Ginecologia, v.11, n.1, p.66-78. 1941.

SÁ, Magali Romero et al.

Medicina, ciência e poder: as relações entre França, Alemanha e Brasil no período de 1919 a 1942. História, Ciências, Saúde - Manguinhos, v.16, n.1, p.247-261. 2009.

SALGADO, Clovis; RIEPER, João Paulo. Colposcopia. Rio de Janeiro: Fundação Nacional de Material Escolar/Ministério da Educação e Cultura. 1970.

\section{SINGLETON, Vicky.}

Stabilizing instabilities: the role of the laboratory in the United Kingdom cervical screening programme. In: Berg, Marc; Mol, Annemarie (Ed.). Differences in medicine: unraveling practices, techniques and bodies. Durham: Duke University Press. p.86-104. 1998.

TEIXEIRA, Luiz Antonio.

O controle do câncer no Brasil na primeira metade do século XX. História, Ciências, SaúdeManguinhos, v.17, supl.1, p.13-31. 2010.

TEIXEIRA, Luiz Antonio.

$\mathrm{O}$ câncer na mira da medicina brasileira. Revista Brasileira de História da Ciência, v.2, n.1, p.104117. 2009.

TEIXEIRA, Luiz Antonio; LÖWY, Ilana. Imperfect tools for a difficult job: colposcopy, "colpocytology" and screening for cervical cancer in Brazil. Social Studies of Science, v.41, n.4, p.585-608. 2011.

TEIXEIRA, Luiz Antonio; PORTO, Marco Antonio Teixeira; SOUZA, Letícia Pumar Alves de. A expansão do rastreio do câncer do colo do útero e a formação de citotécnicos no Brasil. Physis, v.22, n.2, p.713-731. 2012.

TEIXEIRA, Luiz Antonio; PORTO, Marco Antonio; NORONHA, Claudio Pompeiano. O câncer no Brasil: passado e presente. Rio de Janeiro: Outras Letras. 2012.

TEMPERINI, Rosana Soares.

Fundação das Pioneiras Sociais: contribuição inovadora para o Controle do Câncer do Colo do Útero no Brasil (1956-1970). Revista Brasileira de Cancerologia, v.58, n.3, p.339-349. 2012.

THULER, Luis Claudio.

[Depoimento]. Entrevistador: Luiz Antonio Teixeira. Rio de Janeiro: Casa de Oswaldo Cruz. Meio digital (1h22min). Depoimento concedido ao projeto História do câncer: atores, cenários e políticas públicas. 9 out. 2010.

THULER, Luis Claudio.

Editorial: Mortalidade por câncer do colo do útero no Brasil. Revista Brasileira de Ginecologia e Obstetrícia, v.30, n.5, p.216-218. 2008.

THULER, Luis Claudio; ZARDO, Lucilia; ZEFERINO, Luiz.

Perfil dos laboratórios de citopatologia do Sistema Único de Saúde. Jornal Brasileiro de Patologia Médica Laboratorial, v.43, n.2, p.103114. 2007

ZEFERINO, Luiz Carlos.

[Depoimento]. Entrevistador: Luiz Antonio Teixeira. Rio de Janeiro: Casa de Oswaldo Cruz. Meio digital (2h22min). Depoimento concedido ao projeto História do câncer: atores, cenários e políticas públicas. 7 maio 2010 . 